E International

\title{
Liner Shipping Markets, Networks and Strategies
}

The implications for port development on the West coast of South America

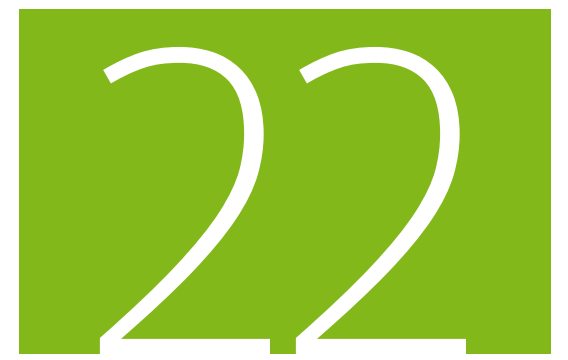

Discussion Paper 2013 22

Gordon Wilmsmeier Economic Commission for Latin America and the Caribbean (ECLAC) 


\title{
International Transport Forum
}

\section{Liner Shipping Markets, Networks and Strategies \\ The implications for port development on the West Coast of South America}

\author{
The case of Chile
}

\section{Discussion Paper No. 2013-22}

Prepared for the Roundtable on

Port Investment and Container Shipping Markets

(7-8 November 2013, Santiago, Chile)

\section{Gordon WILMSMEIER}

Economic Commission for Latin America and the Caribbean (ECLAC)

revised

May 2014 
The International Transport Forum at the OECD is an intergovernmental organisation with 54 member countries. It acts as a strategic think-tank, with the objective of helping shape the transport policy agenda on a global level and ensuring that it contributes to economic growth, environmental protection, social inclusion and the preservation of human life and well-being. The International Transport Forum organises an annual summit of Ministers along with leading representatives from industry, civil society and academia.

The International Transport Forum was created under a Declaration issued by the Council of Ministers of the ECMT (European Conference of Ministers of Transport) at its Ministerial Session in May 2006 under the legal authority of the Protocol of the ECMT, signed in Brussels on 17 October 1953, and legal instruments of the OECD.

The Members of the Forum are: Albania, Armenia, Australia, Austria, Azerbaijan, Belarus, Belgium, Bosnia and Herzegovina, Bulgaria, Canada, Chile, People's Republic of China, Croatia, Czech Republic, Denmark, Estonia, Finland, France, Former Yugoslav Republic of Macedonia, Georgia, Germany, Greece, Hungary, Iceland, India, Ireland, Italy, Japan, Korea, Latvia, Liechtenstein, Lithuania, Luxembourg, Malta, Mexico, Republic of Moldova, Montenegro, the Netherlands, New Zealand, Norway, Poland, Portugal, Romania, Russian Federation, Serbia, Slovak Republic, Slovenia, Spain, Sweden, Switzerland, Turkey, Ukraine, United Kingdom and United States.

The International Transport Forum's Research Centre gathers statistics and conducts co-operative research programmes addressing all modes of transport. I ts findings are widely disseminated and support policymaking in Member countries as well as contributing to the annual summit.

\section{Discussion Papers}

The International Transport Forum's Discussion Paper Series makes economic research, commissioned or carried out at its Research Centre, available to researchers and practitioners. The aim is to contribute to the understanding of the transport sector and to provide inputs to transport policy design.

ITF Discussion Papers should not be reported as representing the official views of the ITF or of its member countries. The opinions expressed and arguments employed are those of the authors.

Discussion Papers describe preliminary results or research in progress by the author(s) and are published to stimulate discussion on a broad range of issues on which the ITF works. Comments on Discussion Papers are welcomed, and may be sent to: International Transport Forum/OECD, 2 rue André-Pascal, 75775 Paris Cedex 16, France.

For further information on the Discussion Papers and other JTRC activities, please email: itf.contact@oecd.org

The Discussion Papers can be downloaded from:

www. internationaltransportforum. org/jtrc/DiscussionPapers/jtrcpapers.html

The International Transport Forum's website is at: www. internationaltransportforum.org

This document and any map included herein are without prejudice to the status of or sovereignty over any territory, to the delimitation of international frontiers and boundaries and to the name of any territory, city or area. 



\section{TABLE OF CONTENTS}

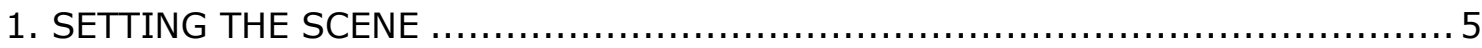

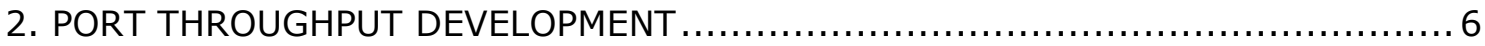

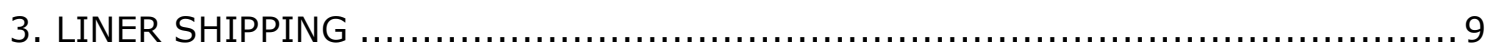

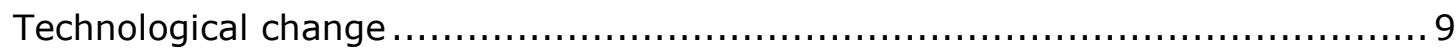

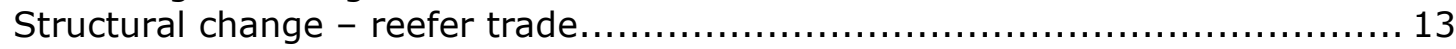

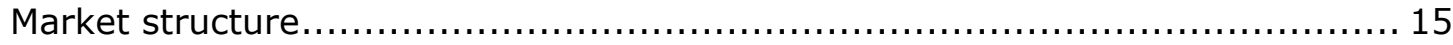

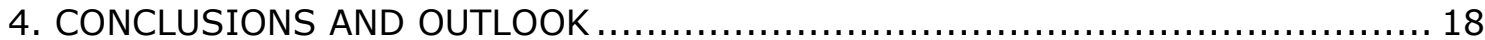

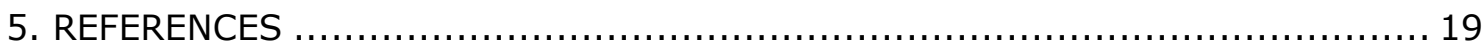





\section{SETTING THE SCENE}

This paper, predominantly on the challenges for port development, in some important sense cannot help but also be about the deeper phenomena of structural change in the maritime industry and geographical shift. The main objective is to analyse the evolution of symptoms of change in the liner shipping industry within South America and more particularly on the West Coast, as these changes are direct drivers of port infrastructure and port system development, which is both economically interesting and a matter of serious policy significance in its own right.

Port infrastructure and the quality of shipping services in a region or country are important determinants of countries' integration in the global market and their competitiveness. Given the sustained growth in emerging economies, despite the recent crisis, port infrastructure development has emerged as a crucial issue for future economic growth. The West Coast of South America (WCSA) and particularly Chile have experienced significant economic expansion over the last two decades. However, the role of infrastructure and its contribution to continued economic and social development has only recently returned to political agendas.

Growth in demand for port infrastructure, structural changes in the maritime industry and the changing geography of trade have clearly revealed the limits of the current transport infrastructure in the region and the country. Infrastructure development decisions, particularly as concerns port infrastructure expansion, are politicised, full of historicism and case-specific empiricism. Thus this work tries to stimulate a more systemic view to support more contextual, integrated and long-term policy decisions. Wilmsmeier et al. (2013) identified critical moments in port development in Latin American and the Caribbean (LAC). Their work focused on the evolution of the port system in the region and its sub-regions. Their findings are the starting point for the present paper, which moves beyond the port to analyse the evolution of and changes in the maritime industry and, more particularly, liner shipping services on the WCSA. Beyond the critical moments identified in the previous work, this paper particularly focuses on the elements of technological change (related to ships), network strategies and liner shipping market structures. 
Figure 1 - Critical Moments in LAC port development, 1990-2013

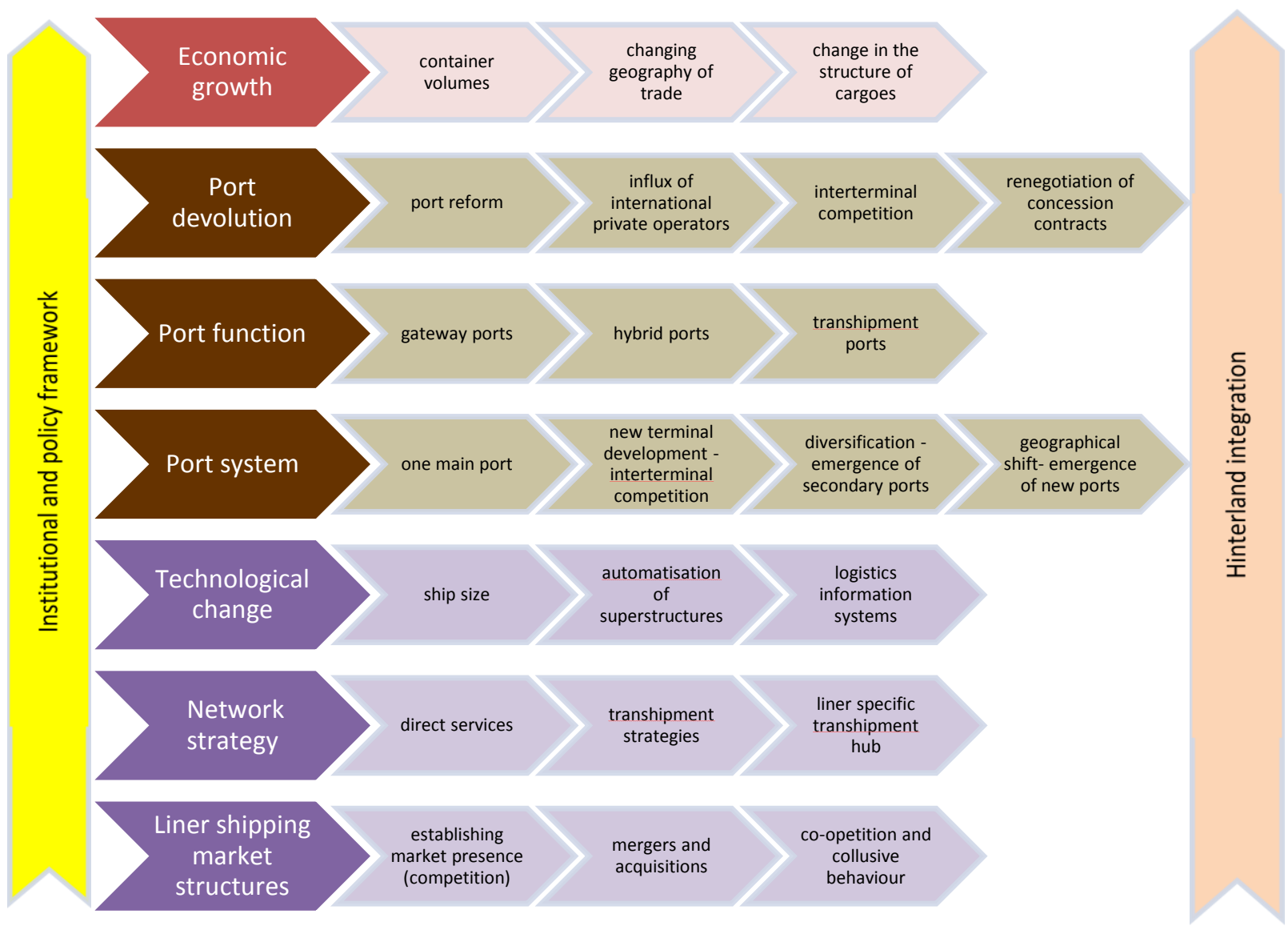

Source: Based on Wilmsmeier et al. (2013).

\section{PORT THROUGHPUT DEVELOPMENT}

Port throughput in Latin America and the Caribbean has grown from 10.4 million TEU (1997) to almost 43 million TEU (2012). At a compound annual growth rate of $9.9 \%$, this development has put enormous pressure on port infrastructure in the region. However, in a global context LAC ports are only responsible for $7.2 \%$ of throughput, with all WCSA ports combined moving only about $1 / 6$ of the TEU of the port of Shanghai.

The analysis of the WCSA port system by Wilmsmeier et al. (2013) hints that ports (represented by their actors, either public or private) were able to make use of critical moments more or less successfully. The port reform processes in the 1990s, notably in Chile, made it possible to advance port infrastructure development, particularly in terms of port productivity, and to initiate significant container terminal development through the involvement of the private sector. However, the sustained growth has brought the prevalent lack of port and transport and logistics infrastructure in the hinterland to light. 
Thus far the focus has been almost exclusively on the development of main container ports, with only residual attention paid to secondary port development in the region. Similarly, port expansion planning is still usually port focused, not developed systemically. Hinterland transport infrastructure and logistical development are also not fully taken into account.

Path dependency and contingency are important elements in the evolution of a port system and its subsystems. Port devolution, competition and hinterland integration strategies, as well as public planning approval, are determinants in this context.

Path dependency is often created by historicism and institutional sclerosis. In Latin America the devolution process in many countries has left port development in the hands of the private sector. Wilmsmeier et al. (2013) refer to Swyngedouw (1992, p. 424e), who argues that "the production of locational effects as a result of capital investment in space", left to private investors, ignores important aspects when creating new ports. Fleming and Hayuth (1994) have also noted how the virtues of centrality and intermediacy that create strategic locations can be manufactured. The question is how this affects future private investment and institutional capacities of current development, particularly in a region where government investment in ports is almost absent. There seems to be clear evidence from the above analysis that the manufacturing of strategic locations can be successful and may have initiated the emergence of secondary ports in LAC.

Ports and port systems undergo lifecycles (Cullinane and Wilmsmeier, 2011) and on the WCSA the traditional main ports have reached maturity. Thus the current discussion on port development needs to be whether it is possible to extend the lifecycle of current locations and what solutions are available, or whether the development of a completely new site in terms of a locational shift is the best option to cater for future development and expansion of the existing port system.

Studies and political discussion on port development in the region have typically focused on the development of a single port, usually a country's main port, thus failing to recognise changes in the overall port system. Wilmsmeier et al. (2013) analyse the evolution of the LAC port system as a whole. Particularly, for the subregion WCSA and its East Coast counterpart (ECSA), the authors find clear indications of decentralisation processes. Over the last decade secondary ports have evolved much faster than the longestablished main gateway ports in both subregions. Thus there is a diversification of ports serving the demand for containerised trade, which is also accompanied by a geographical dispersion of ports.

In the case of Chile, the ports of San Antonio and Valparaiso handled more than twothirds of the total containers moved within the country in 1997. By 2012, these two ports had more than tripled their throughput to over 1.8 million TEU. However, the overall share in container throughput of these two ports has fallen to just above $50 \%$. 
Figure 2 - Evolution of container throughput in Chile, by port, 1997-2011

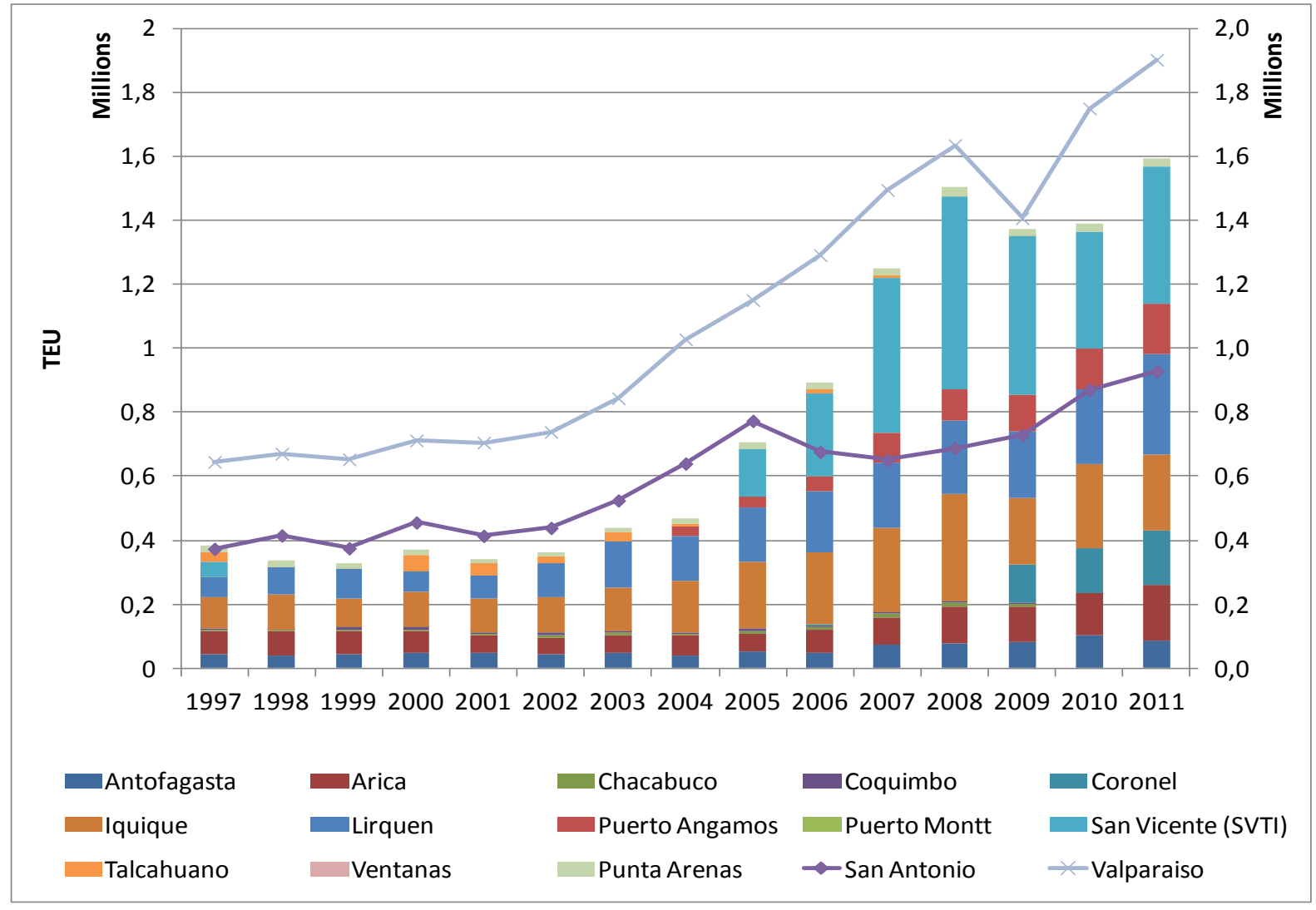

Source: Wilmsmeier et al. (2013).

The ports of Talcahuano, San Vicente Terminal Internacional (SVTI) and Lirquén, all located in very close proximity, have evolved much faster than the traditional ports of San Antonio and Valparaíso. In 1997, SVTI did not even exist, and the others only played a minor role in the port system. In 2012, these three ports moved over one-third of all Chilean container trade.

Such diversification and geographical shift in the port system has occurred in parallel in Brazil and Mexico (Wilmsmeier et al. 2013). This diversification is being driven by the changes in the export structures and thus the emergence of new production centres in the South (especially for perishable products). Additionally, secondary ports are starting to engage in more integrated development strategies, which include consideration of logistics development connected to the port (e.g. Manaus, Brazil; Puerto Angamos, Chile).

The changes in the port system are relevant for Chile's future port development strategy for two reasons: a) expansion of production centres especially in the South but also in other parts of the country leads to a significant increase in hinterland traffic, not only to regional ports but also to the traditional main gateway ports, and b) the shift of economic activity can be expected to result in population increase in the affected regions, creating a new pattern of demand.

Strategies to deal with both factors include infrastructure development to cope with emerging and expanding markets and production centres. This can be achieved by 
expanding road infrastructure, significantly reinforcing the rail network or facilitating coastal shipping.

The available data suggest some evidence for a deconcentration of container traffic within the LAC port system, related to shifts both in gateway regions and from a gateway role to a transhipment role, thus supporting the movement of cargo through secondary LAC ports.

More research is required, but the shifts already identified have potential benefit for secondary ports, many of which are pursuing significant expansion to take advantage of the expected trends. These ports seek to reposition themselves within an emerging feeder market that could reduce the peripherality they experienced in the traditional LAC port and infrastructure system. The paper thus raises questions about port policy and both public and private sector responses to a changing LAC port geography.

\section{LINER SHIPPING}

Analysis of port throughput and weekly capacity supply on the WCSA between 2000 and 2012 reveals a high correlation (0.9) over the whole period. However, the growth rates varied significantly and capacity supply grew faster than port throughput, particularly after the crisis. This section analyses the technological change, capacity development and market structure in liner shipping on the WCSA since 2000.

\section{Technological change}

Technological change in container shipping has unequivocally been a driver of port development. As shipping lines are seeking economies of scale, capacity adjustment has been reached mainly by deploying bigger vessels (Cullinane and Khanna, 1999). The following analyses technological change in terms of ship dimensions (capacity, draught, length and breadth) and its repercussions on port development in the WCSA.

The vessel sizes deployed on the WCSA and in South America in general have conventionally lagged behind the development in the principal trade routes (Perrotti and Sánchez, 2012). However, the evolution of vessel sizes and their TEU capacity dramatically accelerated from the second half of 2008. On the WCSA a significant difference exists between the routes crossing the Panama Canal (WCSA-Europe) and the other main routes (WCSA-Asia and WCSA-North America). In the case of the former, the Panama Canal is the limiting factor; since 2009 Panamax vessels have held an increasing share on this route. On the routes to Asia and North America (WCUS), where this limiting factor is absent, the biggest vessels now deployed can carry over 9000 TEU; in 2008 the maximum vessel capacity was half that. At the same time the average vessel size (TEU capacity) is now above Panamax ship capacity. Figures 3 and 4 clearly depict the acceleration in growth of vessels' TEU capacity since 2008, and with that the cascading effect moving overcapacity from other main routes into secondary markets and thus replacing tonnage. 


\section{Figure 3 - Evolution of vessel capacity on West Coast South America main trade routes, 2000-12}

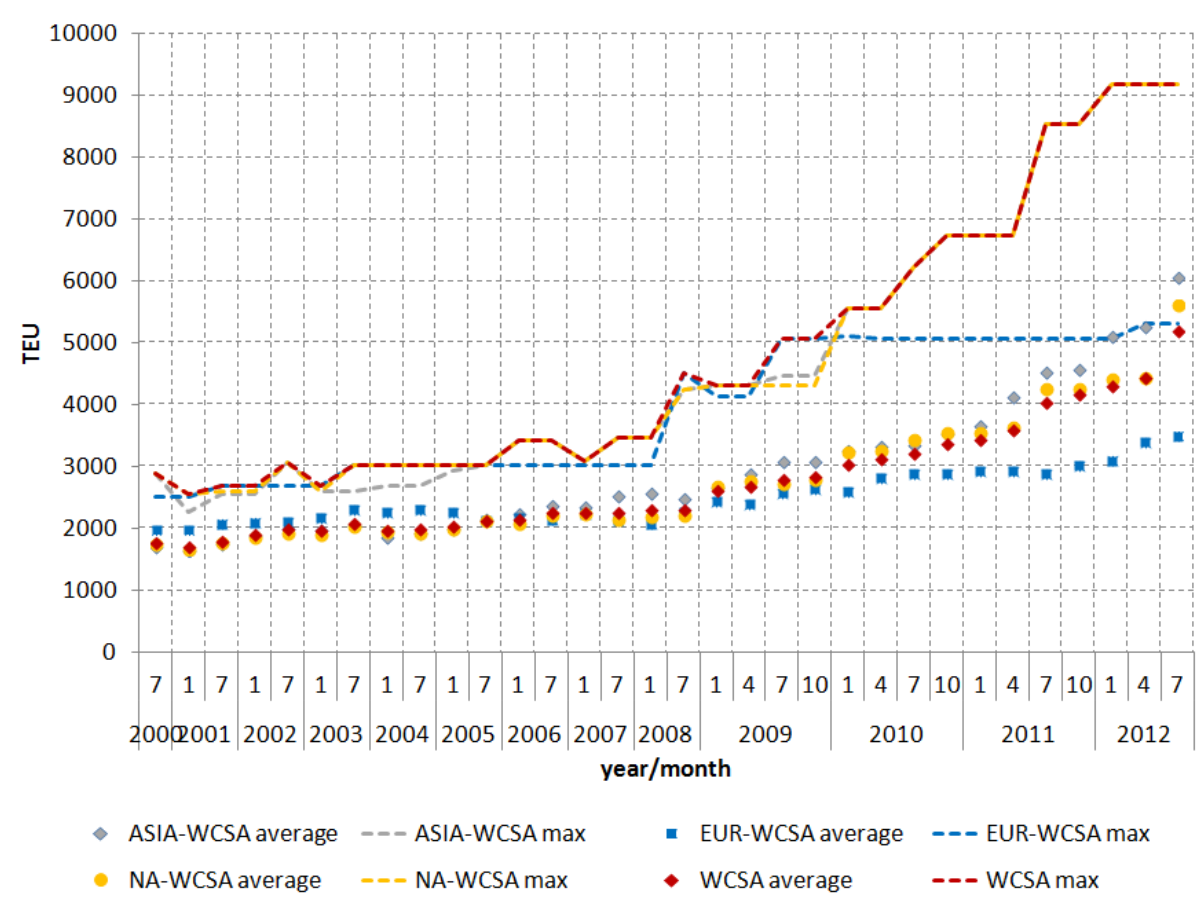

Note: The main trade routes are transpacific, transatlantic and Europe-Asia.

Source: Based on ComPairData, Lloyds List and Marine Traffic, various years.

Figure 4 - Evolution of vessel capacity on South American and other main trade routes, 2000-12

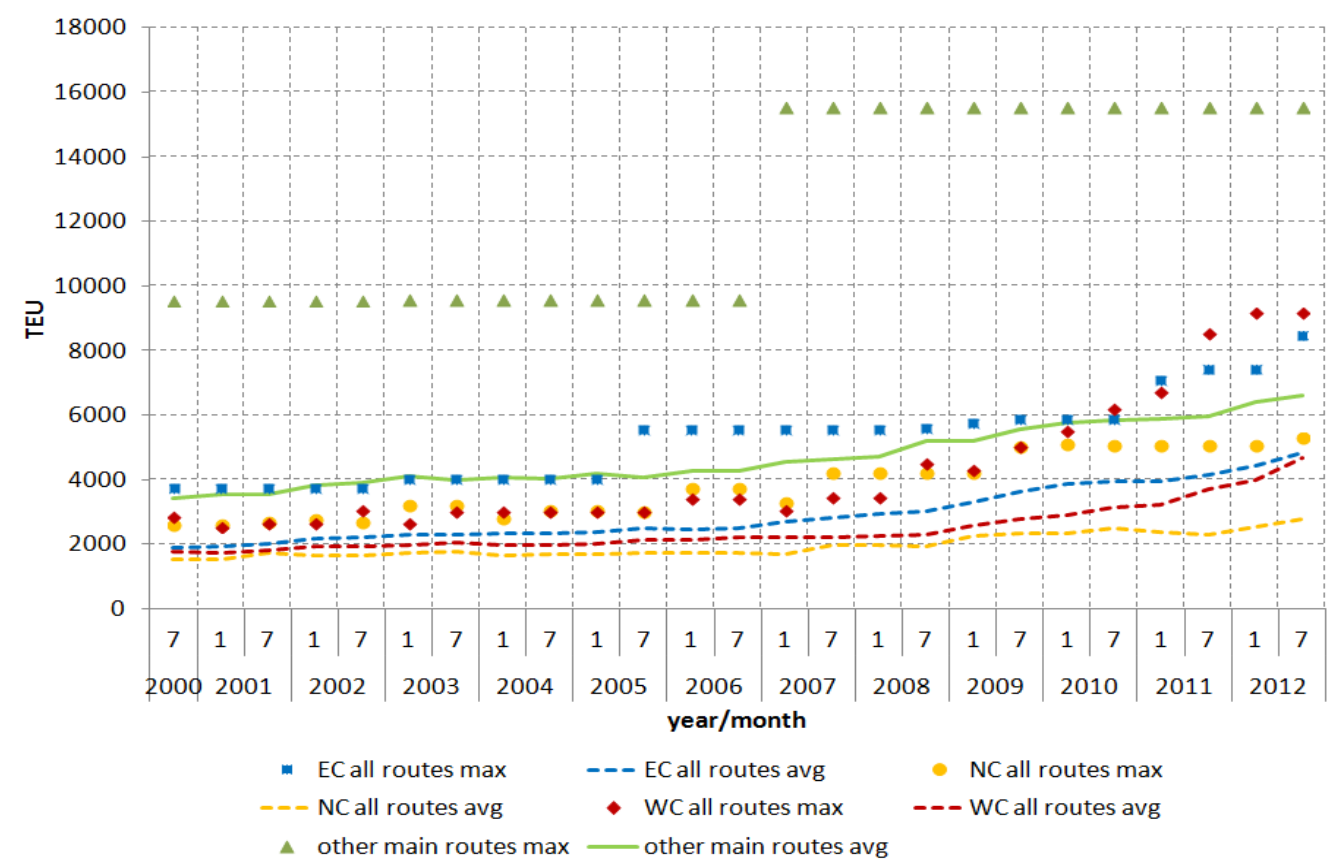

Note: $\mathrm{EC}=$ east coast; $\mathrm{WC}=$ west coast; $\mathrm{NC}=$ north coast; the main trade routes are transpacific transatlantic and Europe-Asia.

Source: Based on ComPairData, Lloyds List and Marine Traffic, various years. 
While there is much talk about the evolution of ship size and related future requirements for infrastructure, an analysis of the evolution of container ships since 2000 on the WCSA reveals that ships with a draught of $15 \mathrm{~m}$ are already a reality. Further, even average draught of deployed vessels has increased by over $2 \mathrm{~m}$ in the past 13 years. Thus, any new port development will have to consider vessel draught of at least $15 \mathrm{~m}$.

\section{Figure 5 - Evolution of vessel draught on South American and other main trade routes, 2000-12}

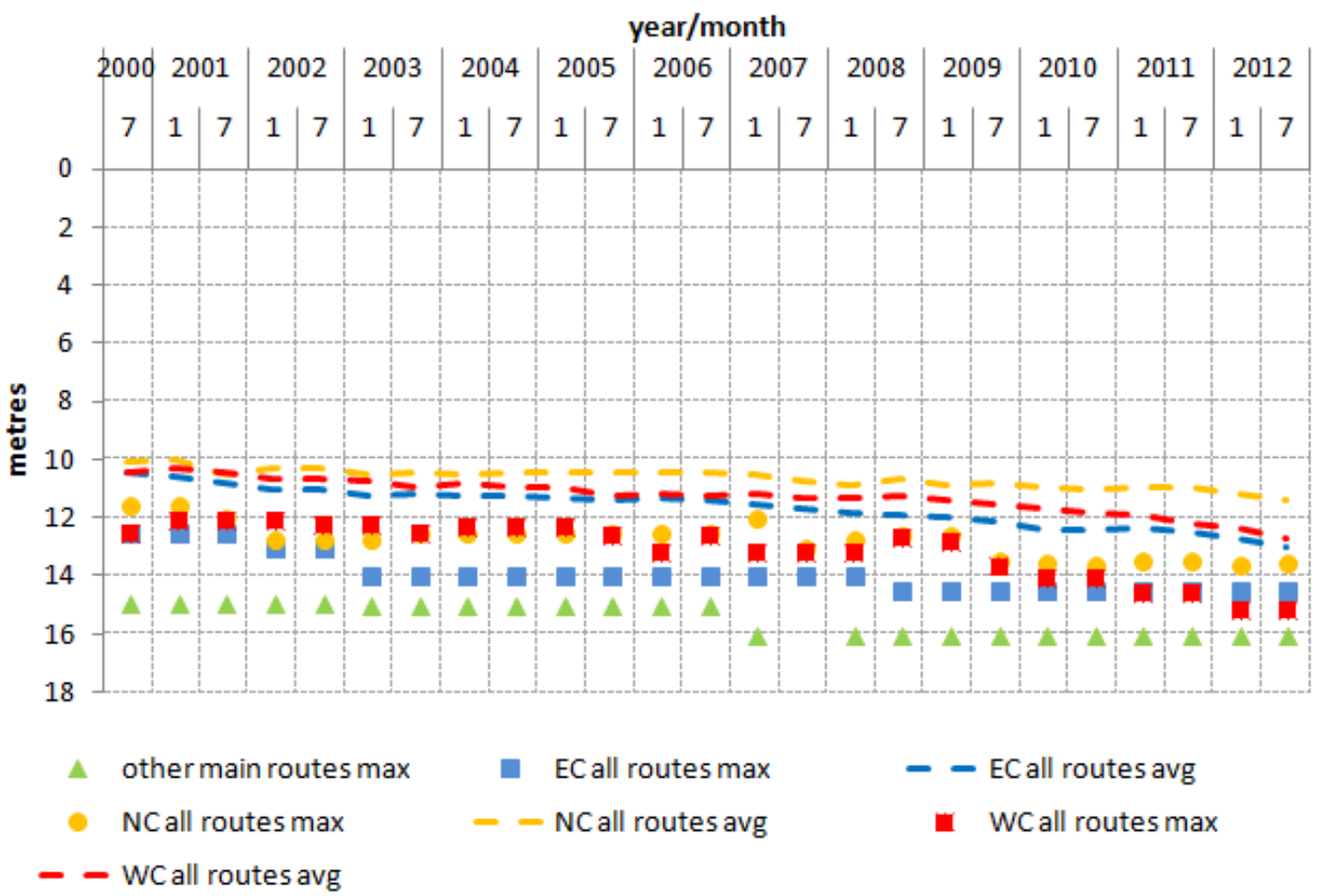

Note: The main trade routes are transpacific, transatlantic and Europe-Asia. The draught considered is the design draught of vessels fully laden.

Source: Based on ComPairData, Lloyds List and Marine Traffic, various years.

Vessel draught is only one aspect of the technological changes to ships that affect port infrastructure requirements. Additional aspects are ship length and breadth. The former determines the quay length and berth layout required to accommodate ships. The latter is a key indicator for superstructure requirements in ports, especially the reach of shipto-shore cranes.

The average vessel length on the WCSA was above $250 \mathrm{~m}$ in 2012 , and the maximum vessel length reached $340 \mathrm{~m}$. In 2000 the maximum vessel length was just above $200 \mathrm{~m}$. Beyond actual length, variation in the length of ships serving a port is of high relevance to port productivity and to planning. Additionally, the breadth of vessels serving the subregion increased from $32.5 \mathrm{~m}$ (2000) to over 45m (2012). 
Figure 6 - Evolution of vessel length on South American and other main trade routes, 2000-12

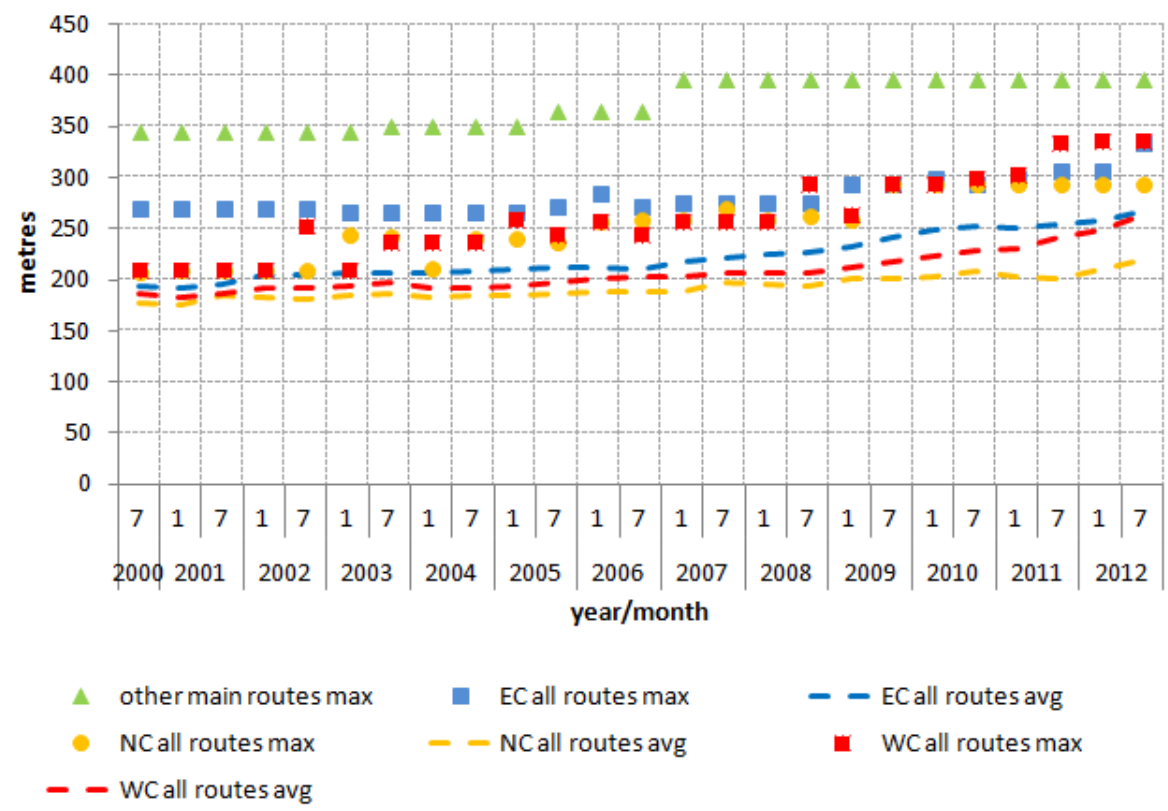

Note: The main trade routes are transpacific, transatlantic and Europe-Asia.

Source: Based on ComPairData, Lloyds List and Marine Traffic, various years.

Figure 7 - Vessel breadth on South American and other main trade routes, 200012

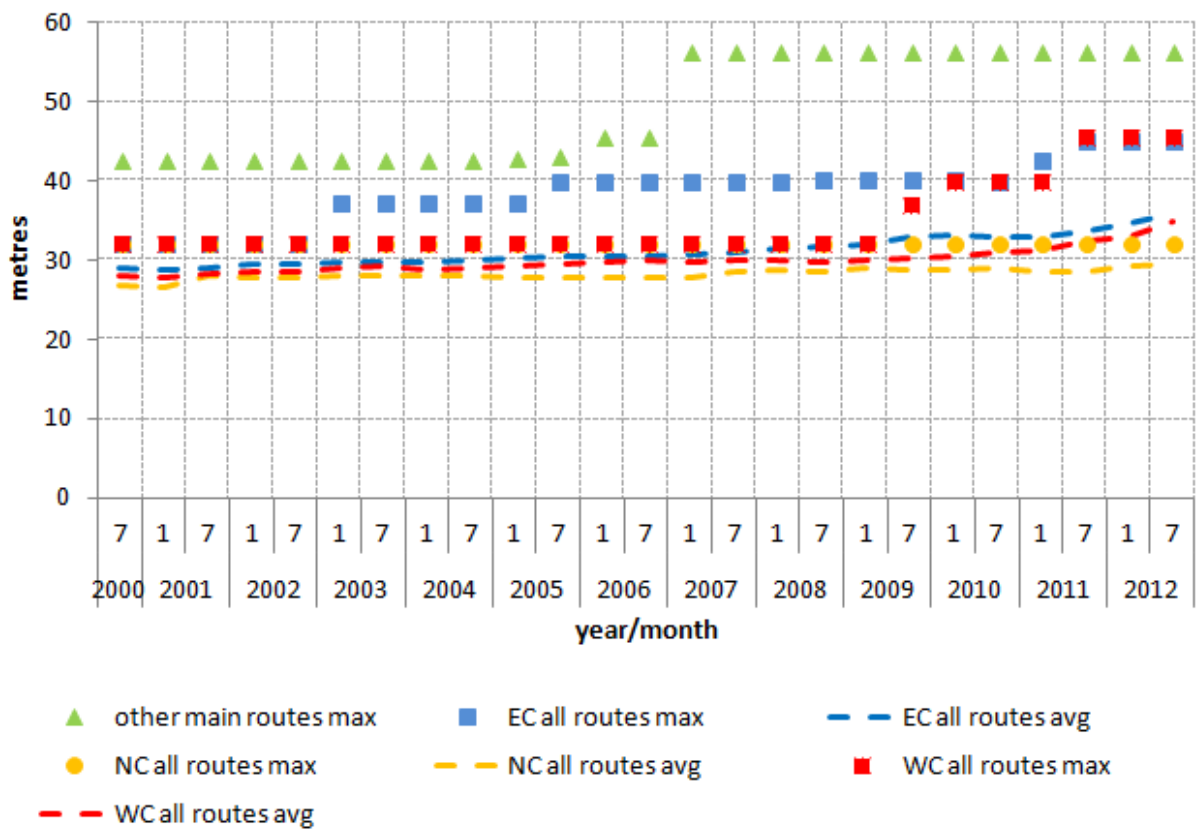

Note: The main trade routes are transpacific, transatlantic and Europe-Asia.

Source: Based on ComPairData, Lloyds List and Marine Traffic, various years.

The observed changes on the WCSA clearly show an acceleration of technological change, particularly since the beginning of the crisis in 2008. At the same time they illustrate the multidimensionality of technological change affecting port development and future port 
plans. The observations indicate increasing pressure to adjust port infrastructure to present requirements, as well as emerging pressure for new port development. A recent study expects 13000 -TEU ships to start calling regularly on the coasts of South America between 2016 and 2020 (Sánchez and Perrotti, 2012). This would have direct implications for the liner shipping networks and port infrastructure in the region. If some secondary ports have insufficient handling capacity to accommodate bigger ships, this would support the growth of regional second-tier hubs, which would be able to serve the smaller ports either by smaller feeders or even land transport (thus raising issues relating to the quality and capacity of hinterland infrastructure links).

Ports on the WCSA urgently need to adjust their available draught capacity to $15 \mathrm{~m}$ and above. In addition, any investment in port superstructure will have to consider a reach for ship-to-shore cranes beyond $50 \mathrm{~m}$, as current ships already require more than $45 \mathrm{~m}$. The latter factor has special relevance, as crane reach requirements will always have to be met; there is no flexibility as in the case of draught, where a less laden vessel will not require the maximum draught.

The introduction of ever-larger vessels on mainline routes may be attractive for shipping lines but will strain ports severely. Ports invest large sums in upgrading their facilities and competing to receive vessel calls, but handling demand spikes is difficult. Large container drops can result in inefficient crane utilisation as the numerous large cranes required to service large ships are not all required between calls; furthermore, large numbers of containers cannot always be moved in and out of port smoothly. Moreover, shipping lines already have trouble meeting their own schedules; current average reliability across the industry is below $70 \%$. The larger the vessel and the greater the volume of transferred containers at each call, the larger the knock-on effect of poor reliability on the rest of the container system.

A further dimension of technological change driven by the emergence of reefer cargo is discussed below.

\section{Structural change - reefer trade}

The global demand for perishable products, especially fruit, has grown substantially, increasing the need for refrigerated seaborne transport capacity. The associated trade flows mainly originate in the southern hemisphere and are directed towards the industrialised countries in the northern hemisphere. In 2010, total seaborne reefer trade was 86.1 million tons, and is expected to reach 112.0 million tonnes by 2016 (Drewry, 2011). WCSA countries exported 14.2 million tonnes of perishable products valued at almost USD 15 billion in 2010, which amounted to 6\% of overall export volume (tonnes) and $9 \%$ of the subregion's total export value (Vagle, 2012, based on BADECEL, 2012). After Ecuador, Chile is the region's largest exporter of perishables in terms of volume, at 4.8 million tonnes. In 2010, the country's export value of perishables was equivalent to $55 \%$ of the whole subregion's export value, reaching almost USD 7.6 billion, making Chile the largest exporter of perishables in terms of value. The average annual growth rate between 1995 and 2010 was $8 \%$ in terms of export value, or twice the rate for export volume (4\%). 
Figure 8 - West Coast South America reefer export evolution, 1995-2011

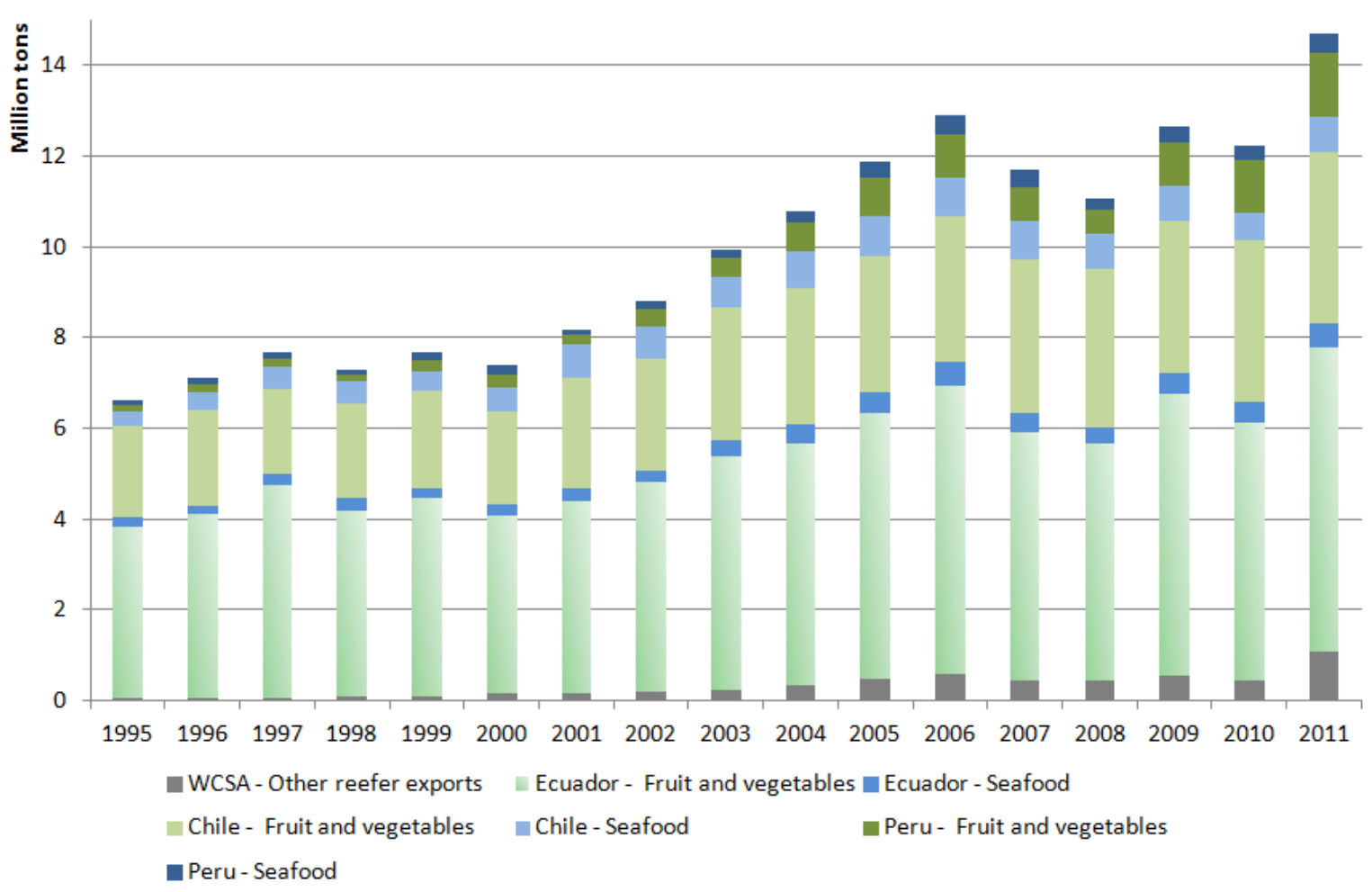

Source: Vagle (2012), based on BADECEL (2012).

The expansion of reefer trade has had important repercussions on the type of vessels deployed in the region, particularly as the transport of reefer cargo has been shifting away from conventional reefer ships to being containerised. For example, between Chile and Northern Europe the share of containerised reefer transport increased from less than $10 \%$ in 2000 to over $65 \%$ in 2011.

The deployed weekly capacity of TEU and reefer plugs on the WCSA more than trebled on the subregion's main routes. The WCSA-Europe route showed the highest share of reefer slots in relation to TEU capacity, $20 \%$ in 2012. On the WCSA-North America and WCSAAsia routes the share of reefer slots was around $12 \%$. The average number of reefer plugs per string in June 2011 was 364. .

This shift is also reflected in the number of reefer slots in the ships deployed in the subregion - up to 1400 per vessel. The WCSA and the ECSA are the regions where ships with the highest number of reefer plugs are being deployed. 
Figure 9 - Reefer capacity of vessels deployed on WCSA main routes, 2000-12

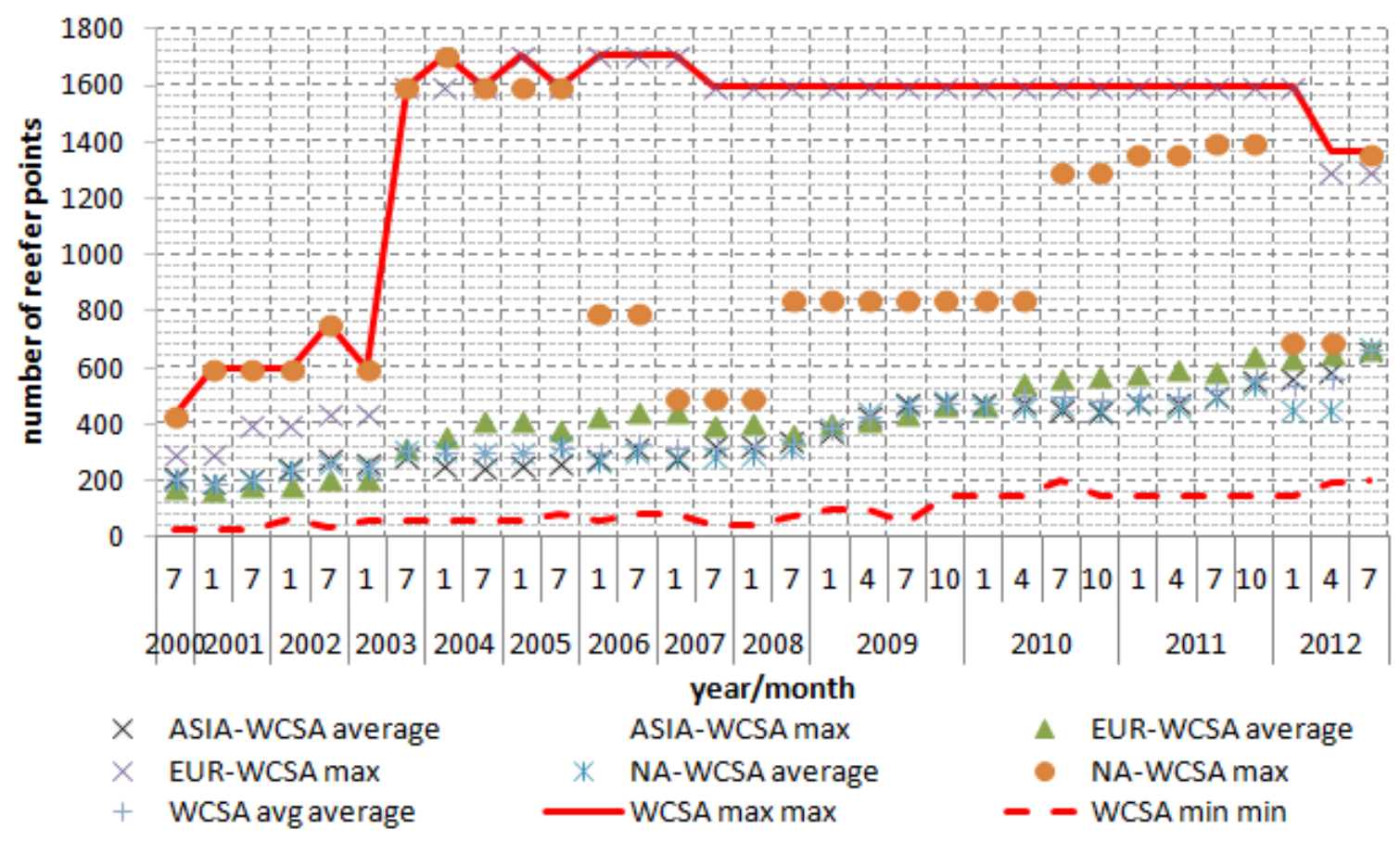

Note: The main trade routes are transpacific, transatlantic and Europe-Asia.

Source: Based on ComPairData, Lloyds List and Marine Traffic, various years.

This structural change in trade also has significant repercussions on ports, as the handling of reefer cargo requires additional installations for cooling and specific services to manage the units. Chile handled around half a million TEU reefer containers in 2012.

\section{Market structure}

From the liner shipping perspective, the region and Chile face the challenges of market concentration and the further evolution of liner shipping networks towards hierarchical networks driven by hub-and-spoke strategies, and they are already affected by the repercussions of the cascading effect in ship deployment, which has led to exponential and accelerated growth of ship sizes deployed in the region.

Nominal capacity in 2012 on the WCSA main routes was 54000 TEU, an increase of $70 \%$ from 2009. The WCSA-North America route experienced the greatest increase $(130 \%)$ over the period, while capacity on the WCSA-Asia route expanded by over $75 \%$. 
Figure 10 - Evolution of weekly capacity supply on WCSA main routes, 2009-12

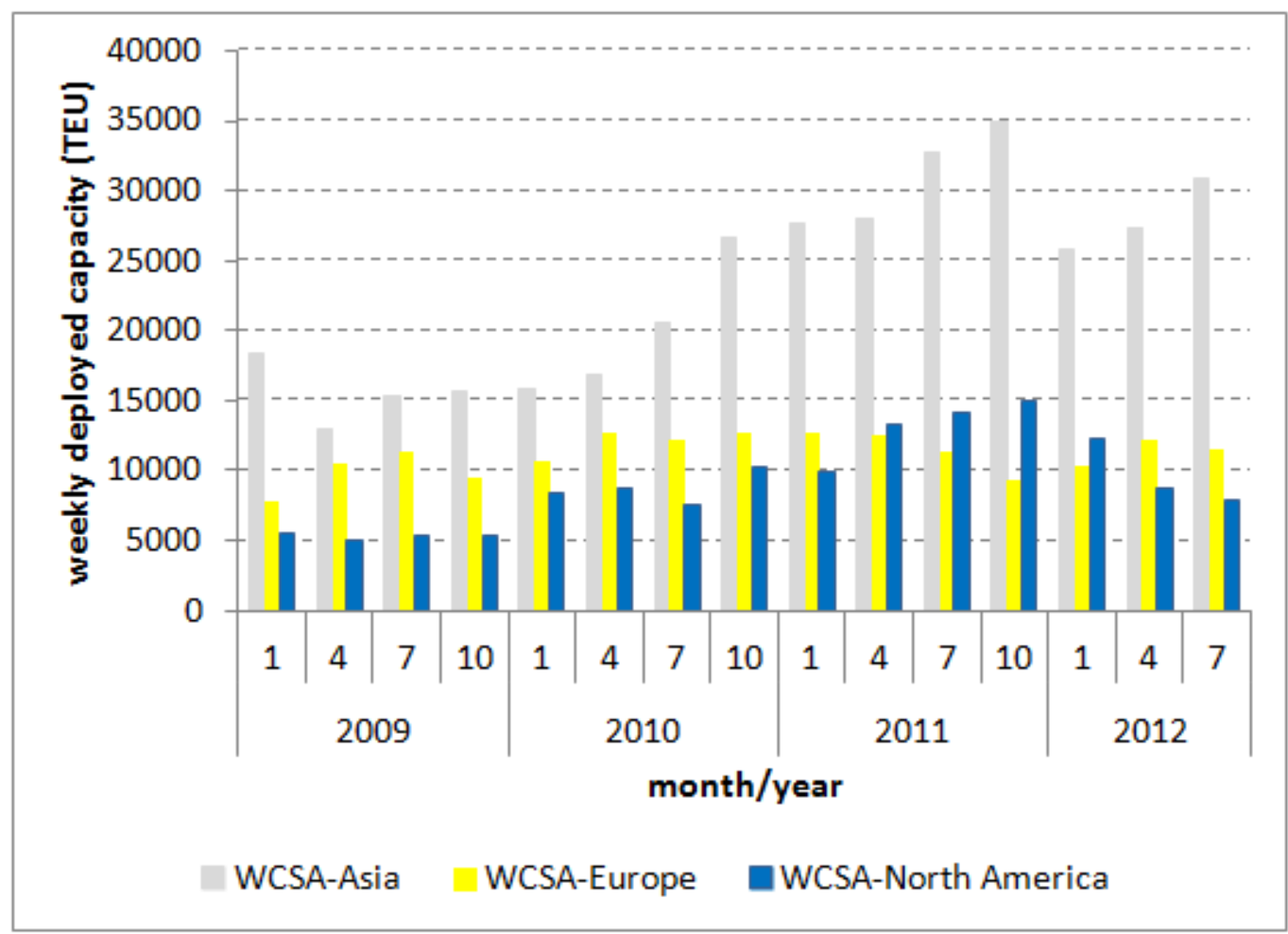

Source: Based on ComPairData, various years.

Nominal capacity increased significantly faster than weekly capacity. The strongest increase in nominal capacity can be observed on the WCSA-Asia services, where it more than doubled between 2008 and 2012. Between 2000 and 2012, nominal deployed capacity on the three main routes (WCSA-Asia, WCSA-Europe and WCSA-North America) quintupled. The differences in nominal capacity are an indicator for the use of slow steaming on the routes, particularly those to Asia and North America.

Beyond capacity, market structure is of high importance to understand potential strategies. In line with Wilmsmeier and Notteboom (2011), a phase of penetration, consolidation and concentration can be observed between 2000 and 2012. At the beginning of the millennium, new operators appeared on the WCSA liner shipping routes (e.g. MSC on the WCSA-Europe route in 2004). Additionally, mergers and acquisitions in the maritime industry had repercussions on the presence of operators in the subregion (notably the takeover of PONL by Maersk). As a result of the crisis, the pattern changed and co-operation between shipping lines, in terms of slot share agreements and jointly operated services, increased. This led to significant movements in the market, as Figure 11 shows for the case of the WCSA-Asia routes. It can be seen that the changes in co-operation and entering and exiting actors particularly increased between April 2010 and January 2012, leading to a period of apparent instability. A result of this period was a significant increase in active operators on the route. However, this was accompanied by a decreasing number of actual services offered. 
Figure 11 - WCSA-Asia changes in market structure, 2000-12
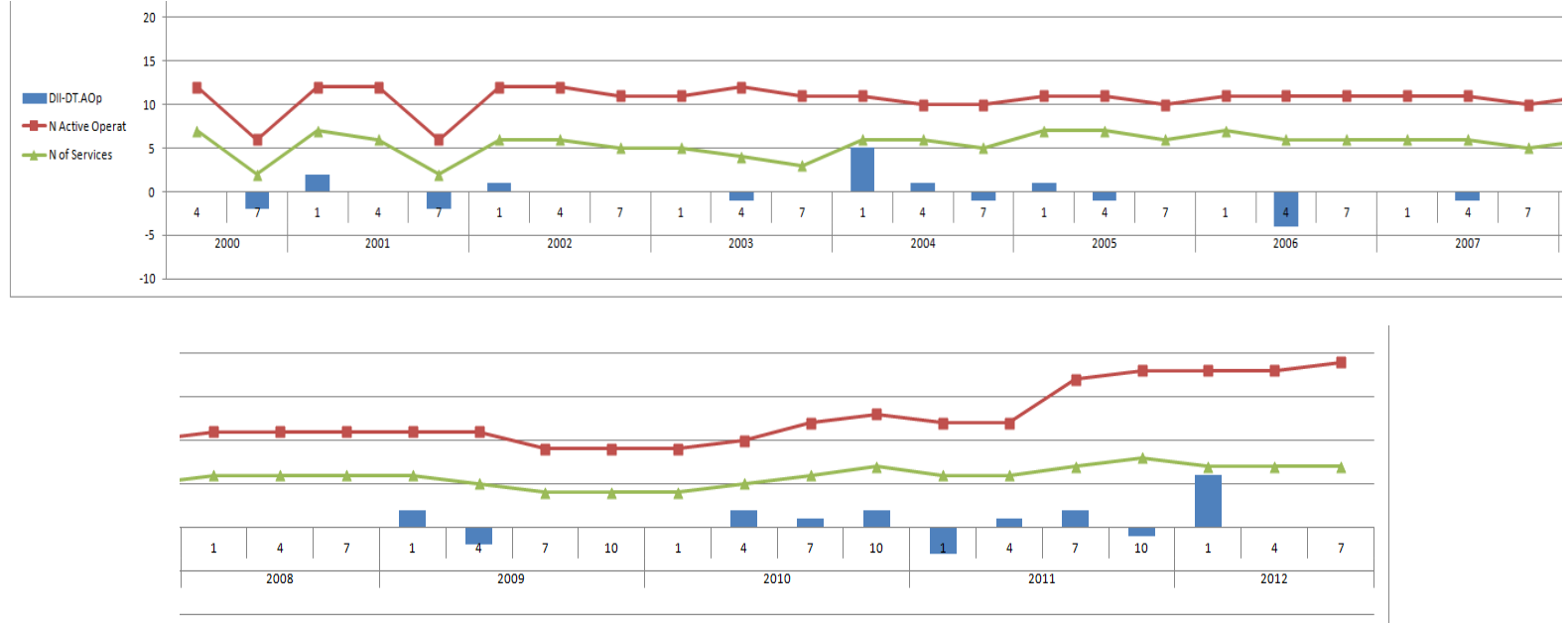

Source: Wilmsmeier and Parushev (2013).

This new form of co-operation also raises questions on the level of competition in the market. Emerging markets such as the WCSA offer a unique opportunity to investigate the behaviour and effectiveness of potential collusive behaviour and pricing. The latter might reduce the competiveness of a country in external trade.

Figure 12, for example, depicts the challenges for the WCSA-Asia route. As the figure shows, five groups compete in this market, despite the fact that more 20 shipping lines are active in the market. Further collaboration between shipping lines carries a risk of quasi-monopolistic markets with potential for collusive behaviour, as is already the case on the WCSA-Europe route.

Figure 12 - Market share in nominal TEU capacity by service, WCSA- Asia, 2000-12

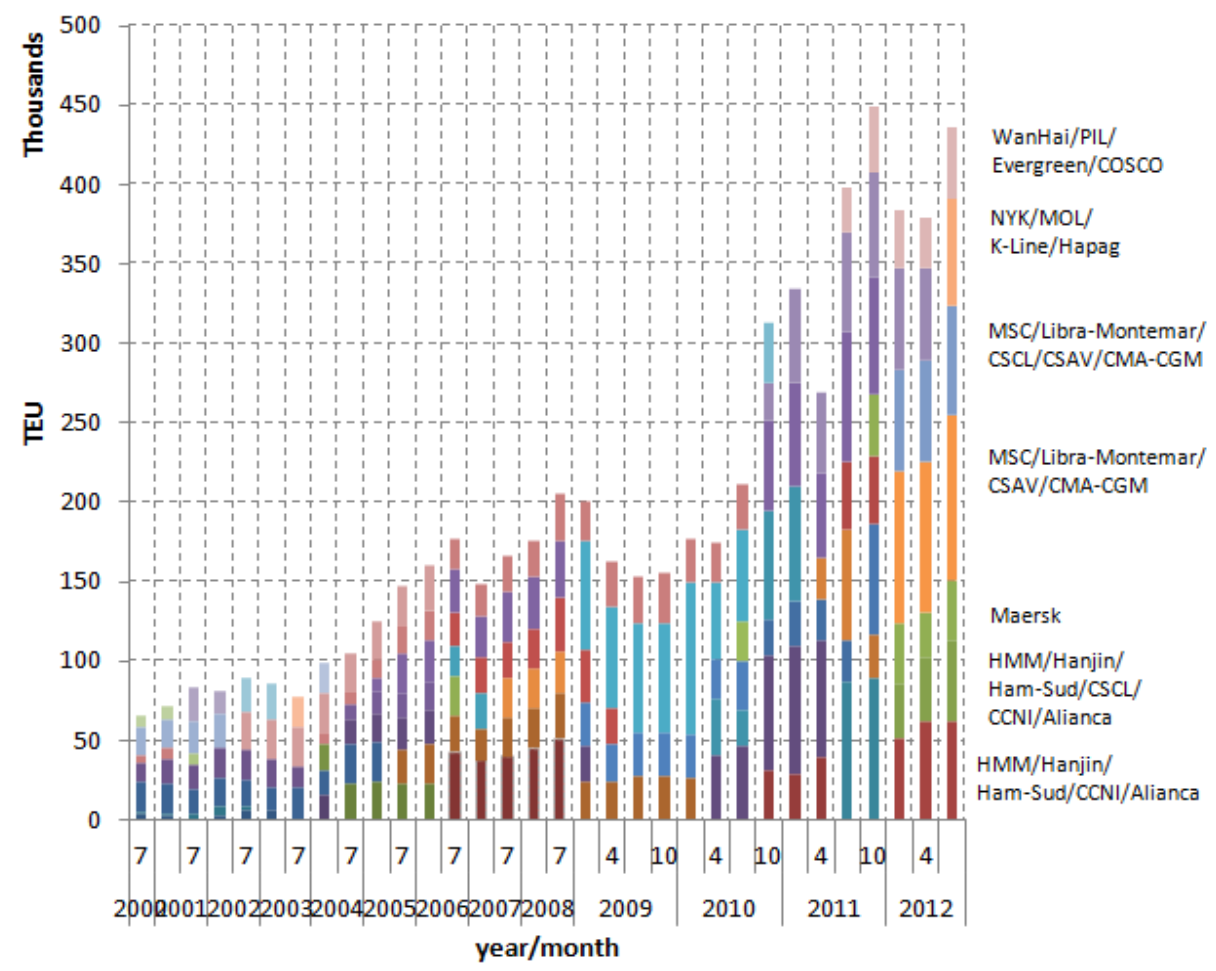


Developments in the liner shipping market have high relevance for future port development, as vertical integration in the market is advancing and thus future port concessions and terminals can result in changes in the competitive environment of the shipping market if a new terminal/port is controlled by a particular group.

\section{CONCLUSIONS AND OUTLOOK}

Port infrastructure in its own right as well as the regional and national port system in Chile are at a crossroads, driven by changes in the maritime liner shipping industry, structural transformation and geographical shifts in trade. Traditional port-focused infrastructure development needs to be extended to include the hinterland, and future port system development will have to reach beyond the established centralist vision. Further, current and future changes in the maritime industry will have to be taken into consideration in long term development strategies.

These shifts entail changes beyond physical development, including at main ports, which require solutions that allow future flexibility. Successful port adaptation to infrastructure development in an increasingly competitive environment can only be achieved if institutions and private sector actors are able to act jointly in critical moments and base their action on integrated visions. 


\section{REFERENCES}

Wilmsmeier, G., J. Monios and G. Perez, 2013, "Port System evolution: the case of Latin America and the Caribbean", paper presented at IAME Annual Conference, Marseille, July 3-5.

Cullinane, K.P.B. and G. Wilmsmeier, 2011, "The contribution of the dry port concept to the extension of port life cycles", in Böse, J.W. (ed), Handbook of Terminal Planning, Springer, New York.

Wilmsmeier, G. and T. Notteboom, 2011 "Determinants of Liner Shipping Network Configuration: A Two Region Comparison, GeoJournal, 76 (3), pp 213-228.

Sánchez, R.J. and D. Perrotti, 2012, "Looking into the future: big full containerships and their arrival to South American ports", Maritime policy and Management, Vol. 39, No. 6, pp. 571-88.

Swyngedouw, E. 1992. Territorial organization and the space/technology nexus. Transactions of the Institute of British Geographers, 17: 417-433.

Vagle, R. 2012, Maritime Reefer Trade in West Coast South America: The case of fruits. Maritime Bulletin (50), October, <http://www.cepal.org/id.asp?id=48153>

Fleming, D. K., Hayuth, Y., 1994, Spatial characteristics of transportation hubs: centrality and intermediacy. Journal of Transport Geography, 2, 3-18.

Wilmsmeier, G. and Parushev, T. 2013 Liner shipping industry - evolution, stability and concentration in South American markets. ECLAC. Working paper.

BADECEL 2012, Base de Datos Estadísticos de Comercio Exterior, Economic Commission for Latin America and the Caribbean (ECLAC) [March, 2012],

<http://websie.eclac.cl/badecel/badecel_new/basededatos.asp >. 
